\title{
Brain Development, Intelligence and Cognitive Outcome in Children Born Small for Gestational Age
}

\author{
H.M.A. de Bie ${ }^{a}$ K.J. Oostrom ${ }^{b}$ H.A. Delemarre-van de Waal ${ }^{a, c}$ \\ Departments of a Pediatrics and ${ }^{\mathrm{b}}$ Medical Psychology, VU University Medical Center, Amsterdam, and \\ 'Department of Pediatrics, Leiden University Medical Center, Leiden, The Netherlands
}

\section{Key Words}

Small for gestational age - Brain development •

Intelligence • Cognition • Growth hormone

\begin{abstract}
Intrauterine growth restriction (IUGR) can lead to infants being born small for gestational age (SGA). SGA is associated with increased neonatal morbidity and mortality as well as short stature, cardiovascular disease, insulin resistance, diabetes mellitus type 2, dyslipidemia and end-stage renal disease in adulthood. In addition, SGA children have decreased levels of intelligence and cognition, although the effects are mostly subtle. The overall outcome of each child is the result of a complex interaction between intrauterine and extrauterine factors. Animal and human studies show structural alterations in the brains of individuals with IUGR/SGA. The presence of growth hormone $(\mathrm{GH})$ receptors in the brain implies that the brain is also a target for $\mathrm{GH}$. Exogenous $\mathrm{GH}$ theoretically has the ability to act on the brain. This is exemplified by the effects of $\mathrm{GH}$ on cognition in $\mathrm{GH}$-deficient adults. In SGA children, data on the effect of exogenous $\mathrm{GH}$ on intelligence and cognition are scant and contradictory.
\end{abstract}

Copyright $\odot 2010$ S. Karger AG, Basel (c) 2010 S. Karger AG, Basel

$1663-2818 / 10 / 0731-0006 \$ 26.00 / 0$

Fax +4161306 1234

E-Mail karger@karger.ch

www.karger.com
Accessible online at: www.karger.com/hrp

\section{Introduction}

Intrauterine growth restriction (IUGR) can lead to infants being born small for gestational age (SGA) [1]. SGA is associated with increased neonatal morbidity and mortality. Also at later ages, these children are often smaller than children born appropriate for gestational age (AGA) [1]. Furthermore, SGA children are at risk for cardiovascular disease, insulin resistance, diabetes mellitus type 2, dyslipidemia and end-stage renal disease in adulthood [1]. In addition to a negative influence on these physical and metabolic parameters, decreased levels of intelligence and cognition have been described in SGA children. However, the nature and severity of these intellectual and cognitive vulnerabilities differ widely between study populations [2].

Intelligence comprises a set of abilities to understand, learn and apply knowledge and can be expressed in terms of an intelligence quotient (IQ). Cognition is the knowledge-handling aspect of behavior and can be discerned in the following cognitive domains: speech and language, visuospatial and visuoconstructive skills, motor skills, learning and memory, attention and executive functions such as planning, problem-solving and self-monitoring [3].

Both intelligence and cognition are determined by genetic diversity and variations in the pre- and postnatal 
environment. Intelligence and cognition can be regarded as functions of the brain [3]. Given the observed decreased intellectual and cognitive abilities of SGA children, it can be expected that brain architecture and brain functioning differ between SGA and AGA children.

Interest in this topic has increased since the approval of growth hormone $(\mathrm{GH})$ therapy for treatment of SGA children [4]. The effect of GH therapy on height has been carefully documented [1]. Interestingly, one group described an effect of GH on intelligence and cognition in SGA children [5], whereas another group did not find any significant effect of GH on intelligence [6].

In this review, we summarize the literature on brain development after IUGR in animals and humans. Furthermore, we have reviewed and analyzed studies on intelligence and cognition in SGA children. Finally, we discuss the effects of exogenous $\mathrm{GH}$ on the brain, intelligence and cognition.

\section{Definitions}

IUGR is defined as a process of reduced fetal growth velocity resulting in a failure of the fetus to attain its growth potential. It is a prenatal diagnosis, based on serial ultrasound measurements during pregnancy [7]. Unfortunately, for most pregnancies multiple ultrasound measurements are not available. SGA is defined as a birth weight and/or length below a predefined cutoff limit [7]. A group of SGA children therefore will not only include children born small due to IUGR, but also constitutionally small children. When, for example, the 5 th percentile is taken as the cutofflimit, approximately $20 \%$ of the children termed SGA will not be growth restricted but constitutionally small [8]. To study the effects of IUGR, in most studies a predefined cutoff limit is used, although from a methodological point the use of serial ultrasounds is preferable [7].

\section{Brain Development after IUGR}

\section{Studies in Animals}

Since it is very difficult to obtain specimens for histopathological study of human IUGR brains, most of the knowledge of the central nervous system in IUGR has been derived from animal studies. Different methods to induce chronic IUGR have been used in various animal species (mostly rat, sheep and guinea pig) to study the effects on the brain of IUGR in mid- or late gestation. Fre-

Brain Development, Intelligence and Cognitive Outcome in SGA Children quently used methods are uterine artery ligation, embolization or malnutrition [9]. The cerebral cortex, hippocampus and cerebellum are the areas most extensively studied.

In IUGR animals, total body weight and brain weight are reduced. However, brain weight is reduced to a lesser extent, indicating that the brain is relatively spared [10]. When investigated, both hippocampus and cerebellum have reduced volume compared to controls [11-13]. Histopathological studies demonstrate a reduced cortical thickness and a reduced number of neurons in IUGR animals $[11,12,14-16]$. Neuronal migration to the cortex can be delayed [17], and dendritic and axonal outgrowth is retarded $[12,18,19]$. In addition, delayed and reduced myelination was evident $[12,18,20,21]$. There are many factors that contribute to the distribution and severity of the brain damage found in IUGR animals. The timing, duration and severity of the growth restriction in relation to the schedule of brain development of several areas within the brain determine the extent of brain damage in each species [22]. In summary, IUGR animal experiments demonstrate that IUGR results in variable outcomes of abnormal fetal brain development.

\section{Studies in Humans}

There are very few postmortem studies of human brains of SGA children [23]. In a small group of term SGA infants without documented IUGR, reduced brain weight and cell number in the brain were found compared to normal birth weight controls of similar age [23]. In addition, the total amount and concentration of myelin lipids was reduced in SGA infants. With magnetic resonance imaging it is possible to study brain anatomy in humans in vivo. Imaging studies in combination with ultrasound measurements of fetuses during pregnancy reveal that, despite brain sparing, IUGR leads to a reduction of brain volume [24]. Several studies in premature infants with documented IUGR and children born SGA have shown a reduction of total brain volume, most pronounced in cerebral cortical gray matter [25-27]. The degree of volume reduction was well correlated with both head circumference and functional outcome at term, especially attention [26]. In contrast to brain volume, cortical gyrus and sulcus formation is less affected [25].

Unfortunately, there are no longitudinal magnetic resonance imaging studies of brain development in SGA children from birth onwards. In adolescents born SGA at term with postnatal catch-up growth, a trend towards smaller cerebral cortical volume was found compared to control adolescents, but this difference was not signifi- 
Table 1. Intelligence and cognition in children born SGA, compared to children born AGA (matched for gestational age)

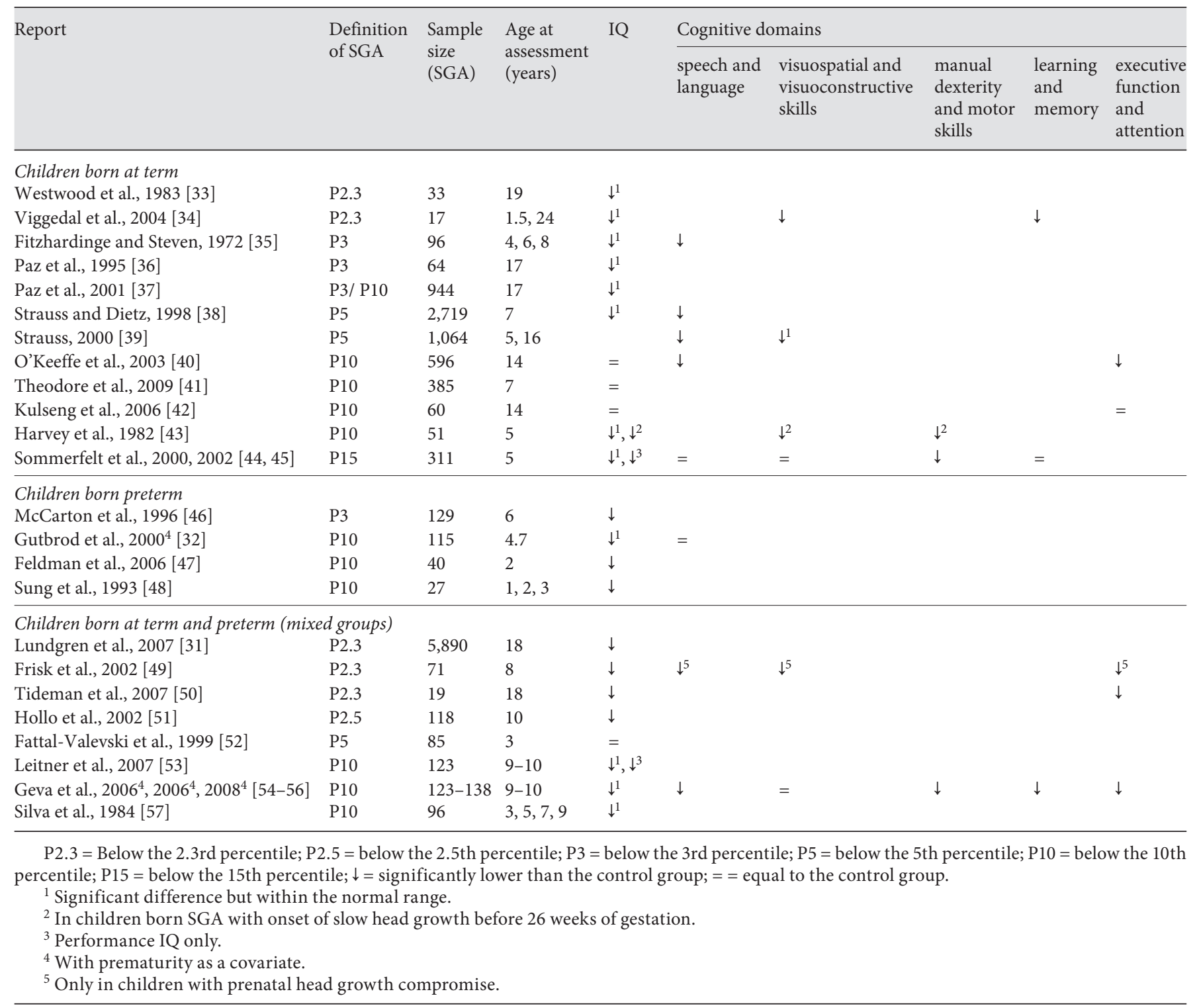

cant $[28,29]$. Studies in SGA children without catch-up growth are not available.

In summary, both animal and human studies demonstrate a consistent underdevelopment of the brain in animals and children born SGA.

\section{Intelligence and Cognition in Children Born SGA}

We reviewed studies investigating intelligence and cognition in children born SGA. We included studies reporting results derived from intelligence and cognitive tests performed by the children themselves. Studies based on questionnaires filled in by parents or schoolteachers were excluded. Another inclusion criterion was a control group consisting of children born AGA with similar gestational age. Studies as early as possible were included, dating from 1972 until February 2009.

Because prematurity is an independent risk factor of inferior outcome in intelligence and cognition [30-32], studies were grouped according to gestational age into term children or preterm children (table 1) [31-57]. 


\section{Children Born at Term}

For the studies included in table 1, the birth weight cutoff for defining SGA varied widely, ranging from below the 2.3 rd percentile to below the 15 th percentile. The group size also differed considerably. In most studies, IQ was assessed only once, but in some studies children were tested repeatedly with several years in between.

From table 1, it is clear that in most studies the IQ in SGA children is significantly lower than in AGA controls. However, this difference never exceeded 1 standard deviation (15 IQ points). Within studies, the more severely affected SGA children had the lowest IQ. The difference in IQ score between SGA and AGA children was positively related to the birth weight cutoff. In general, studies with more stringent criteria for defining SGA reported larger differences in IQ scores between SGA children and AGA controls, but this association must be interpreted with caution because many different test batteries with different psychometric properties were used.

For the different cognitive domains, considerably fewer data are available. When tested, SGA children performed worse on various cognitive domains compared to their normal counterparts. Given the widespread cognitive vulnerabilities in the different studies, it can be expected that when tested systematically, SGA children will perform worse across various cognitive domains. This is exemplified by the fact that SGA children have poorer school performance and experience more learning difficulties [31, 51, 55].

\section{Children Born Preterm}

As can be expected, for children born preterm, the IQ in both AGA and SGA groups was lower than that of children born at term. Still, most studies found a significantly lower IQ in preterm children born SGA compared to preterm children born AGA.

\section{Conceptual Model of Intelligence and Cognition in Children Born SGA}

Being born SGA places a child at risk for impairments in intelligence and cognition, but, as stated earlier, the overall outcome of each individual is the result of a complex interaction between several factors, as visualized in figure 1. Some of these factors operate independently, while others are associated with being born SGA, i.e. perinatal morbidity and lower socioeconomic status [31, $32,41,46,51,52]$.

Brain Development, Intelligence and Cognitive Outcome in SGA Children
Intrauterine factors that determine growth and growth restriction can be divided into fetal, maternal and placental factors [58]. The severity of growth restriction [40], prenatal head growth pattern $[31,43,49]$ and perinatal complications including prematurity $[31,33,52]$ are key players in determining the outcome of the SGA child at birth.

After birth, postnatal catch-up growth of both the body and head can follow various patterns. Good catchup growth is associated with better outcome at later ages with respect to IQ and cognition [31, 49, 55]. Remaining factors determining the final outcome in SGA children are psychosocial and genetic factors. The most important factors are the home and school environment, socioeconomic status and parental intelligence $[33,41,44]$.

\section{GH and the Brain}

\section{Distribution of GH Receptors}

From animal studies, it is known that GH receptors (GHRs) as well as insulin-like growth factor (IGF)-I receptors are found on all cell types of the brain. They are most abundant in the fetal and juvenile brain and decline thereafter with age [59]. GHR distribution in the human neonatal brain is largely unknown. Only one study using human fetal brain has been published and demonstrates the existence of GHRs on neurons of the cerebral cortex [60]. Studies in human adults demonstrate the presence of GHRs and IGF-I receptors in different areas of the human brain but mainly concentrated in the choroid plexus, pituitary, hippocampus, putamen and hypothalamus [61].

\section{Origin of Production of $\mathrm{GH}$}

While local production of $\mathrm{GH}$ in the brain (neural $\mathrm{GH}$ ) of animals is clearly demonstrated, local production of GH in the human brain is less clear [62]. Although the blood-brain barrier was generally considered to be impermeable to peripheral (or pituitary) GH, both animal and human studies have demonstrated that peripheral GH can pass the blood-brain barrier [61, 63, 64]. During pregnancy, human placental $\mathrm{GH}$, also named $\mathrm{GH} 2$ or $\mathrm{GH}-\mathrm{V}$, is secreted by the placenta and gradually replaces maternal pituitary $\mathrm{GH}$ [65].

\section{Action of GH in the Brain}

The presence of GHRs in the developing brain suggests a role for $\mathrm{GH}$ in neural development and neural function. Using cell culture systems, it was found that $\mathrm{GH}$ 


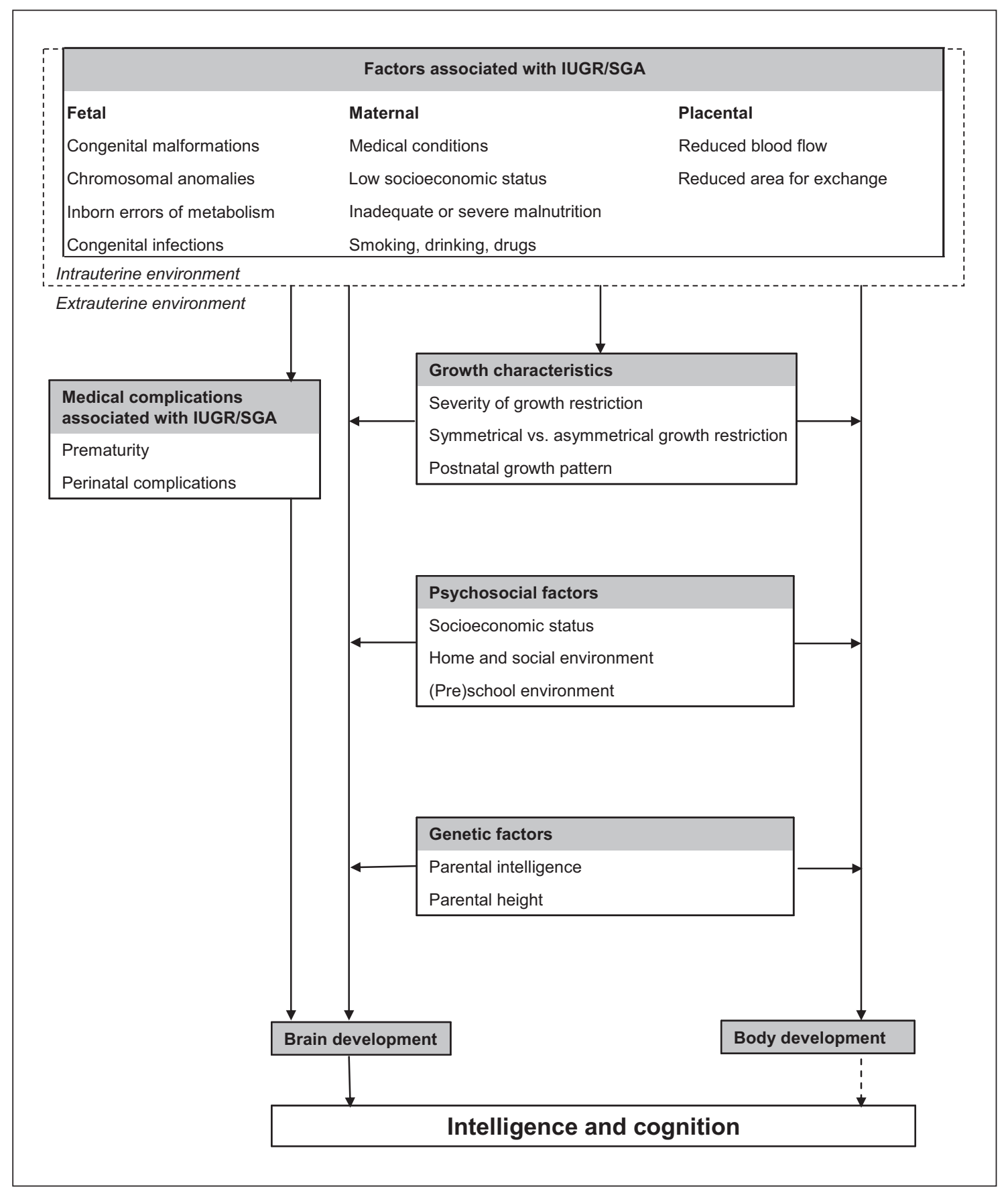

Fig. 1. Conceptual model of intelligence and cognition in children born SGA. Adapted from Noeker [2], with permission.

induces neuronal and glial proliferation and differentiation $[61,66]$. GH-deficient mice have a microcephalic brain that is hypomyelinated, with retarded neuronal growth and poor synaptogenesis. GH administered during critical stages of brain development increases brain size in GH-deficient mice [61, 67]. Animal studies further demonstrate that $\mathrm{GH}$ has a neuroprotective effect following hypoxic-ischemic injury $[68,69]$.

Some but not all the effects of GH are thought to be mediated via IGF-I $[59,66,70]$. Animal studies show an 
important role of IGF-I in brain growth and development, with demonstrated effects on the proliferation and differentiation of neurons and glial cells and synaptogenesis [70-74]. IGF-I knockout mice have reduced brain size, whereas mice with transgenic overexpression of IGF-I have increased brain size [75, 76]. In addition, IGFI promotes cell survival through antiapoptotic actions [77]. Clinical studies in patients with IGF-I deficiency due to a genetic defect of the IGF-I gene reveal microcephaly and psychomotor retardation, and an association has been described between IGF-I levels and intelligence in childhood [78, 79].

In conclusion, GH and IGF-1 both possess multiple common effects in the brain. The specific effects of $\mathrm{GH}$ and the effects of GH mediated by IGF-1 in the brain remain to be determined.

\section{GH Therapy and Brain Development, Intelligence and Cognition in Humans}

The presence of GHRs in areas of the brain that are thought to be involved in neurocognitive functioning indicates that substitution of GH in various patient groups may positively influence brain development and subsequently intelligence and cognition.

The effect of GH therapy on intelligence and cognition has been investigated in both children and adults. The effect of GH therapy on intelligence and cognition has been studied in children with GH deficiency, idiopathic short stature and Prader-Willi and Turner syndromes. No clear beneficial effects of GH therapy on IQ and cognition have been described in these patient groups, although the number of studies is very limited [80,81]. Adults with GH deficiency have IQs within the normal range. Several studies indicate that GH deficiency can lead to minor but clinically relevant cognitive impairment. Most extensively studied are memory, processing speed and attention [82]. In contrast with the lack of effect of exogenous GH in children, GH therapy has been shown to have a beneficial effect on cognition in adults [82].

\section{GH Therapy in Children Born SGA}

There are 2 cohorts of SGA children in which the effect of GH therapy on intelligence and cognition has been evaluated $[5,6,83,84]$.

In the Netherlands, children born SGA without catchup growth were evaluated after 2 and 8 years of GH treatment $[5,83,84]$. In 53 treated children, a positive effect of
GH treatment on performance and total IQ scores as well as attention was found. After 8 years of GH treatment, estimated IQ scores of SGA children had increased by $5-10$ points and were in the same range as the normal population. In addition, the investigators found a relation between the change in head circumference and the improvement of estimated IQ scores during GH treatment. These results are in contrast with the findings in a cohort of SGA children from Belgium. In a randomized controlled trial, no beneficial effect of GH treatment on IQ scores could be observed after 2 years of treatment [6]. A remarkable finding in this study was an increase in IQ scores of about 8 points in untreated SGA children. The treated group, consisting of 17 children, did not show an increase in IQ scores, despite a clear effect of GH therapy on head circumference.

There are several methodological issues that must be kept in mind when interpreting these IQ scores. Firstly, in the Dutch study, an estimated IQ score was reported that was based on 2 out of 12 subscales of the Wechsler Intelligence Scale for Children-Revised. Secondly, the changes in IQ scores after 8 years may have been influenced by the Flynn effect, i.e. an increase in IQ over generations. This problem can be overcome by using an appropriate control group. Thirdly, changes in test instruments (from preschool children to school children) may have influenced the IQ scores in the Belgian study, because they were unevenly distributed between treated and untreated groups.

In summary, there is no conclusive evidence that $\mathrm{GH}$ treatment in SGA children has an effect on IQ.

\section{Exogenous GH in IUGR Animal Models}

Unfortunately, animal studies on the effect of exogenous GH on brain development and cognition in IUGR models are lacking. Exogenous GH improves learning processes in rats, but this type of experiment has not been performed in IUGR animals $[85,86]$.

\section{Conclusions}

IUGR leads to abnormal and delayed brain development. SGA is associated with decreased levels of intelligence and various cognitive problems, although the effects are mostly subtle. The overall outcome of each child is the result of a complex interaction between intrauterine and extrauterine factors. The presence of GHRs in the brain implies that the brain is also a target for GH. Exogenous GH theoretically has the ability to act on the brain. 
This is exemplified by the effects of GH treatment on cognition in adult GH-deficient patients. Data on the effect of exogenous $\mathrm{GH}$ on intelligence and cognition in SGA children are scant and contradictory. Therefore, thorough follow-up studies in GH-treated SGA children are needed to resolve this issue.

\section{Acknowledgements}

We thank Mrs. I. Riphagen, University Library, VU University Medical Center, for her bibliographic assistance. We thank Ms. M. Boersma for careful reading of the manuscript. This work was funded by an educational grant from Pfizer BV, The Netherlands.

\section{References}

1 Saenger P, Czernichow P, Hughes I, Reiter EO: Small for gestational age: short stature and beyond. Endocr Rev 2007;28:219-251.

$\checkmark 2$ Noeker M: Neurocognitive development in children experiencing intrauterine growth retardation and born small for gestational age: pathological, constitutional and therapeutic pathways. Horm Res 2005;64(suppl 3):83-88.

3 Kinsbourne M, Graf WD: Disorders of mental development; in Menkes JH, Sarnat HB (eds): Child Neurology. Philadelphia, Lippincott Williams \& Wilkins, 2000, pp 11551211.

- 4 Lee PA, Chernausek SD, Hokken-Koelega AC, Czernichow P; International Small for Gestational Age Advisory Board: International Small for Gestational Age Advisory Board consensus development conference statement: management of short children born small for gestational age, April 24-October 1, 2001. Pediatrics 2003;111:12531261.

5 Van Pareren YK, Duivenvoorden HJ, Slijper FS, Koot HM, Hokken-Koelega AC: Intelligence and psychosocial functioning during long-term growth hormone therapy in children born small for gestational age. J Clin Endocrinol Metab 2004;89:5295-5302.

6 Lagrou K, Vanderfaeillie J, Froidecoeur C, Thomas M, Massa G, Tenoutasse S, Craen M, Lebrethon MC, Beckers D, Francois I, Rooman R, Thiry-Counson G, Beaufort de C, De SJ: Effect of 2 years of high-dose growth hormone therapy on cognitive and psychosocial development in short children born small for gestational age. Eur J Endocrinol 2007;156:195-201.

7 Bertino E, Milani S, Fabris C, De CM: Neonatal anthropometric charts: what they are, what they are not. Arch Dis Child Fetal Neonatal Ed 2007;92:F7-F10.

8 Mamelle N, Cochet V, Claris O: Definition of fetal growth restriction according to constitutional growth potential. Biol Neonate 2001;80:277-285.

9 Vuguin PM: Animal models for small for gestational age and fetal programming of adult disease. Horm Res 2007;68:113-123.

10 Morrison JL: Sheep models of intrauterine growth restriction: fetal adaptations and consequences. Clin Exp Pharmacol Physiol 2008;35:730-743.
11 Lister JP, Blatt GJ, DeBassio WA, Kemper TL, Tonkiss J, Galler JR, Rosene DL: Effect of prenatal protein malnutrition on numbers of neurons in the principal cell layers of the adult rat hippocampal formation. Hippocampus 2005;15:393-403.

12 Mallard C, Loeliger M, Copolov D, Rees S: Reduced number of neurons in the hippocampus and the cerebellum in the postnatal guinea-pig following intrauterine growthrestriction. Neuroscience 2000;100:327333.

13 Mallard EC, Rehn A, Rees S, Tolcos M, Copolov D: Ventriculomegaly and reduced hippocampal volume following intrauterine growth-restriction: implications for the aetiology of schizophrenia. Schizophr Res 1999; 40:11-21.

14 Hayakawa M, Mimura S, Sasaki J, Watanabe K: Neuropathological changes in the cerebrum of IUGR rat induced by synthetic thromboxane A2. Early Hum Dev 1999;55: 125-136.

15 Rees S, Bocking AD, Harding R: Structure of the fetal sheep brain in experimental growth retardation. J Dev Physiol 1988;10:211-225.

16 Tashima L, Nakata M, Anno K, Sugino N, Kato H: Prenatal influence of ischemia-hypoxia-induced intrauterine growth retardation on brain development and behavioral activity in rats. Biol Neonate 2001;80:81-87.

17 Sasaki J, Fukami E, Mimura S, Hayakawa M, Kitoh J, Watanabe K: Abnormal cerebral neuronal migration in a rat model of intrauterine growth retardation induced by synthetic thromboxane A(2). Early Hum Dev 2000;58:91-99.

18 Mallard EC, Rees S, Stringer M, Cock ML, Harding R: Effects of chronic placental insufficiency on brain development in fetal sheep. Pediatr Res 1998;43:262-270.

19 Dieni S, Rees S: Dendritic morphology is altered in hippocampal neurons following prenatal compromise. J Neurobiol 2003;55:4152.

20 Nitsos I, Rees S: The effects of intrauterine growth retardation on the development of neuroglia in fetal guinea pigs. An immunohistochemical and an ultrastructural study. Int J Dev Neurosci 1990;8:233-244.
21 Sizonenko SV, Borradori-Tolsa C, Bauthay DM, Lodygensky G, Lazeyras F, Huppi P: Impact of intrauterine growth restriction and glucocorticoids on brain development: insights using advanced magnetic resonance imaging. Mol Cell Endocrinol 2006;254255:163-171.

22 Morgane PJ, Mokler DJ, Galler JR: Effects of prenatal protein malnutrition on the hippocampal formation. Neurosci Biobehav Rev 2002;26:471-483.

23 Chase HP, Welch NN, Dabiere CS, Vasan NS, Butterfield LJ: Alterations in human brain biochemistry following intrauterine growth retardation. Pediatrics 1972;50:403-411.

24 Duncan KR, Issa B, Moore R, Baker PN, Johnson IR, Gowland PA: A comparison of fetal organ measurements by echo-planar magnetic resonance imaging and ultrasound. BJOG 2005;112:43-49.

25 Dubois J, Benders M, Borradori-Tolsa C, Cachia A, Lazeyras F, Ha-Vinh LR, Sizonenko SV, Warfield SK, Mangin JF, Huppi PS: Primary cortical folding in the human newborn: an early marker of later functional development. Brain 2008;131:2028-2041.

26 Tolsa CB, Zimine S, Warfield SK, Freschi M, Sancho RA, Lazeyras F, Hanquinet S, Pfizenmaier M, Huppi PS: Early alteration of structural and functional brain development in premature infants born with intrauterine growth restriction. Pediatr Res 2004; 56:132-138.

27 Toft PB, Leth H, Ring PB, Peitersen B, Lou HC, Henriksen O: Volumetric analysis of the normal infant brain and in intrauterine growth retardation. Early Hum Dev 1995;43: 15-29.

28 Martinussen M, Fischl B, Larsson HB, Skranes J, Kulseng S, Vangberg TR, Vik T, Brubakk AM, Haraldseth O, Dale AM: Cerebral cortex thickness in 15-year-old adolescents with low birth weight measured by an automated MRI-based method. Brain 2005; $128: 2588-2596$.

29 Skranes JS, Martinussen M, Smevik O, Myhr G, Indredavik M, Vik T, Brubakk AM: Cerebral MRI findings in very-low-birth-weight and small-for-gestational-age children at 15 years of age. Pediatr Radiol 2005;35:758765 . 
30 Yanney M, Marlow N: Paediatric consequences of fetal growth restriction. Semin Fetal Neonatal Med 2004;9:411-418.

- 31 Lundgren EM, Cnattingius S, Jonsson B, Tuvemo $\mathrm{T}$ : Intellectual and psychological performance in males born small for gestational age with and without catch-up growth. Pediatr Res 2001;50:91-96.

- 32 Gutbrod T, Wolke D, Soehne B, Ohrt B, Riegel K: Effects of gestation and birth weight on the growth and development of very low birthweight small for gestational age infants: a matched group comparison. Arch Dis Child Fetal Neonatal Ed 2000;82:F208F214.

-33 Westwood M, Kramer MS, Munz D, Lovett JM, Watters GV: Growth and development of full-term nonasphyxiated small-for-gestational-age newborns: follow-up through adolescence. Pediatrics 1983;71:376-382.

34 Viggedal G, Lundalv E, Carlsson G, Kjellmer I: Neuropsychological follow-up into young adulthood of term infants born small for gestational age. Med Sci Monit 2004;10:CR8CR16.

-35 Fitzhardinge PM, Steven EM: The small-fordate infant. II. Neurological and intellectual sequelae. Pediatrics 1972;50:50-57.

-36 Paz I, Gale R, Laor A, Danon YL, Stevenson DK, Seidman DS: The cognitive outcome of full-term small for gestational age infants at late adolescence. Obstet Gynecol 1995;85: 452-456.

- 37 Paz I, Laor A, Gale R, Harlap S, Stevenson DK, Seidman DS: Term infants with fetal growth restriction are not at increased risk for low intelligence scores at age 17 years. J Pediatr 2001;138:87-91.

38 Strauss RS, Dietz WH: Growth and development of term children born with low birth weight: effects of genetic and environmental factors. J Pediatr 1998;133:67-72.

-39 Strauss RS: Adult functional outcome of those born small for gestational age: twentysix-year follow-up of the 1970 British Birth Cohort. JAMA 2000;283:625-632.

- 40 O'Keeffe MJ, O'Callaghan M, Williams GM, Najman JM, Bor W: Learning, cognitive, and attentional problems in adolescents born small for gestational age. Pediatrics 2003; 112:301-307.

41 Theodore RF, Thompson JM, Waldie KE, Becroft DM, Robinson E, Wild CJ, Clark PM, Mitchell EA: Determinants of cognitive ability at 7 years: a longitudinal case-control study of children born small-for-gestational age at term. Eur J Pediatr 2009;168:12171224.

42 Kulseng S, Jennekens-Schinkel A, Naess P, Romundstad P, Indredavik M, Vik T, Brubakk AM: Very-low-birthweight and term small-for-gestational-age adolescents: attention revisited. Acta Paediatr 2006;95:224230.
43 Harvey D, Prince J, Bunton J, Parkinson C, Campbell S: Abilities of children who were small-for-gestational-age babies. Pediatrics 1982;69:296-300.

44 Sommerfelt K, Andersson HW, Sonnander K, Ahlsten G, Ellertsen B, Markestad T, Jacobsen G, Hoffman HJ, Bakketeig L: Cognitive development of term small for gestational age children at five years of age. Arch Dis Child 2000;83:25-30.

45 Sommerfelt K, Sonnander K, Skranes J, Andersson HW, Ahlsten G, Ellertsen B, Markestad T, Jacobsen G, Hoffman HJ, Bakketeig LS: Neuropsychologic and motor function in small-for-gestation preschoolers. Pediatr Neurol 2002;26:186-191.

46 McCarton CM, Wallace IF, Divon M, Vaughan HG Jr: Cognitive and neurologic development of the premature, small for gestational age infant through age 6: comparison by birth weight and gestational age. Pediatrics 1996;98:1167-1178.

47 Feldman R, Eidelman AI: Neonatal state organization, neuromaturation, mother-infant interaction, and cognitive development in small-for-gestational-age premature infants. Pediatrics 2006;118:e869-e878.

48 Sung IK, Vohr B, Oh W: Growth and neurodevelopmental outcome of very low birth weight infants with intrauterine growth retardation: comparison with control subjects matched by birth weight and gestational age. J Pediatr 1993;123:618-624.

49 Frisk V, Amsel R, Whyte HE: The importance of head growth patterns in predicting the cognitive abilities and literacy skills of small-for-gestational-age children. Dev Neuropsychol 2002;22:565-593.

50 Tideman E, Marsal K, Ley D: Cognitive function in young adults following intrauterine growth restriction with abnormal fetal aortic blood flow. Ultrasound Obstet Gynecol 2007;29:614-618.

51 Hollo O, Rautava P, Korhonen T, Helenius H, Kero P, Sillanpaa M: Academic achievement of small-for-gestational-age children at age 10 years. Arch Pediatr Adolesc Med 2002; 156:179-187.

52 Fattal-Valevski A, Leitner Y, Kutai M, TalPosener E, Tomer A, Lieberman D, Jaffa A, Many A, Harel S: Neurodevelopmental outcome in children with intrauterine growth retardation: a 3-year follow-up. J Child Neurol 1999;14:724-727.

53 Leitner Y, Fattal-Valevski A, Geva R, Eshel R, Toledano-Alhadef H, Rotstein M, Bassan H, Radianu B, Bitchonsky O, Jaffa AJ, Harel S: Neurodevelopmental outcome of children with intrauterine growth retardation: a longitudinal, 10-year prospective study. J Child Neurol 2007;22:580-587.

54 Geva R, Eshel R, Leitner Y, Fattal-Valevski A, Harel S: Memory functions of children born with asymmetric intrauterine growth restriction. Brain Res 2006;1117:186-194.
55 Geva R, Eshel R, Leitner Y, Valevski AF, Harel S: Neuropsychological outcome of children with intrauterine growth restriction: a 9-year prospective study. Pediatrics 2006;118:91-100.

56 Geva R, Eshel R, Leitner Y, Fattal-Valevski A, Harel S: Verbal short-term memory span in children: long-term modality dependent effects of intrauterine growth restriction. J Child Psychol Psychiatry 2008;49:13211330.

57 Silva PA, McGee R, Williams S: A longitudinal study of the intelligence and behavior of preterm and small for gestational age children. J Dev Behav Pediatr 1984;5:1-5.

58 Bryan SM, Hindmarsh PC: Normal and abnormal fetal growth. Horm Res 2006; 65(suppl 3):19-27.

59 Lobie PE, Zhu T, Graichen R, Goh EL: Growth hormone, insulin-like growth factor I and the CNS: localization, function and mechanism of action. Growth Horm IGF Res 2000;10(suppl B):S51-S56.

60 Hill DJ, Riley SC, Bassett NS, Waters MJ: Localization of the growth hormone receptor, identified by immunocytochemistry, in second trimester human fetal tissues and in placenta throughout gestation. J Clin Endocrinol Metab 1992;75:646-650.

61 Harvey S, Hull K: Neural growth hormone: an update. J Mol Neurosci 2003;20:1-14.

62 Harvey S, Lavelin I, Pines M: Growth hormone $(\mathrm{GH})$ action in the brain: neural expression of a GH-response gene. J Mol Neurosci 2002;18:89-95.

-63 Johansson JO, Larson G, Andersson M, Elmgren A, Hynsjo L, Lindahl A, Lundberg PA, Isaksson OG, Lindstedt S, Bengtsson BA: Treatment of growth hormone-deficient adults with recombinant human growth hormone increases the concentration of growth hormone in the cerebrospinal fluid and affects neurotransmitters. Neuroendocrinology 1995;61:57-66.

64 Pan W, Yu Y, Cain CM, Nyberg F, Couraud PO, Kastin AJ: Permeation of growth hormone across the blood-brain barrier. Endocrinology 2005; 146:4898-4904

65 Mirlesse V, Frankenne F, Alsat E, Poncelet M, Hennen G, Evain-Brion D: Placental growth hormone levels in normal pregnancy and in pregnancies with intrauterine growth retardation. Pediatr Res 1993;34:439-442.

-66 Ajo R, Cacicedo L, Navarro C, SanchezFranco F: Growth hormone action on proliferation and differentiation of cerebral cortical cells from fetal rat. Endocrinology 2003; 144:1086-1097.

67 Noguchi T: Effects of growth hormone on cerebral development: morphological studies. Horm Res 1996;45:5-17.

68 Scheepens A, Sirimanne ES, Breier BH, Clark RG, Gluckman PD, Williams CE: Growth hormone as a neuronal rescue factor during recovery from CNS injury. Neuroscience 2001;104:677-687. 
69 Shin DH, Lee E, Kim JW, Kwon BS, Jung MK, Jee YH, Kim J, Bae SR, Chang YP: Protective effect of growth hormone on neuronal apoptosis after hypoxia-ischemia in the neonatal rat brain. Neurosci Lett 2004;354:64-68.

70 Russo VC, Gluckman PD, Feldman EL, Werther GA: The insulin-like growth factor system and its pleiotropic functions in brain. Endocr Rev 2005;26:916-943.

71 Arsenijevic Y, Weiss S: Insulin-like growth factor-I is a differentiation factor for postmitotic CNS stem cell-derived neuronal precursors: distinct actions from those of brainderived neurotrophic factor. J Neurosci 1998; 18:2118-2128.

-72 Arsenijevic Y, Weiss S, Schneider B, Aebischer P: Insulin-like growth factor-I is necessary for neural stem cell proliferation and demonstrates distinct actions of epidermal growth factor and fibroblast growth factor2. J Neurosci 2001;21:7194-7202.

73 D’Ercole AJ, Ye P, O’Kusky JR: Mutant mouse models of insulin-like growth factor actions in the central nervous system. Neuropeptides 2002;36:209-220.

74 Ye P, Li L, Richards RG, DiAugustine RP, D'Ercole AJ: Myelination is altered in insulin-like growth factor-I null mutant mice. J Neurosci 2002;22:6041-6051.
Beck KD, Powell-Braxton L, Widmer HR, Valverde J, Hefti F: Igf1 gene disruption results in reduced brain size, CNS hypomyelination, and loss of hippocampal granule and striatal parvalbumin-containing neurons. Neuron 1995;14:717-730.

76 Carson MJ, Behringer RR, Brinster RL, McMorris FA: Insulin-like growth factor I increases brain growth and central nervous system myelination in transgenic mice. Neuron 1993;10:729-740.

77 Hodge RD, D’Ercole AJ, O’Kusky JR: Insulin-like growth factor-I (IGF-I) inhibits neuronal apoptosis in the developing cerebral cortex in vivo. Int J Dev Neurosci 2007;25: 233-241.

78 Gunnell D, Miller LL, Rogers I, Holly JM: Association of insulin-like growth factor I and insulin-like growth factor-binding protein-3 with intelligence quotient among 8- to 9-year-old children in the Avon Longitudinal Study of Parents and Children. Pediatrics 2005;116:e681-e686.

79 Walenkamp MJ, Wit JM: Single gene mutations causing SGA. Best Pract Res Clin Endocrinol Metab 2008;22:433-446.

80 Ross JL: Effects of growth hormone on cognitive function. Horm Res 2005;64(suppl 3):89-94.

81 Myers SE, Whitman BY, Carrel AL, Moerchen V, Bekx MT, Allen DB: Two years of growth hormone therapy in young children with Prader-Willi syndrome: physical and neurodevelopmental benefits. Am J Med Genet A 2007;143:443-448.
82 Falleti MG, Maruff P, Burman P, Harris A: The effects of growth hormone $(\mathrm{GH})$ deficiency and GH replacement on cognitive performance in adults: a meta-analysis of the current literature. Psychoneuroendocrinology 2006;31:681-691.

83 Van der Reijden-Lakeman IE: Growing pains? Psychological evaluation of children with short stature after intrauterine growth retardation, before and after two years of growth hormone treatment. Thesis. Rotterdam, Erasmus University, 1996.

84 Van der Reijden-Lakeman IE, Sonneville de LM, Swaab-Barneveld HJ, Slijper FM, Verhulst FC: Evaluation of attention before and after 2 years of growth hormone treatment in intrauterine growth retarded children. J Clin Exp Neuropsychol 1997;19:101-118.

85 Schneider-Rivas S, Paredes-Carbajal C, Mascher D, Angoa-Perez M, Jaramillo-Gonzalez E, Borgonio-Perez G, Rivas-Arancibia $S$ : Effects of testosterone and growth hormone on long-term retention and extinction of a passive avoidance response in young and aged rats. Int J Neurosci 2007;117:14431456.

86 Le Greves M, Zhou Q, Berg M, Le Greves P, Fholenhag K, Meyerson B, Nyberg F: Growth hormone replacement in hypophysectomized rats affects spatial performance and hippocampal levels of NMDA receptor subunit and PSD-95 gene transcript levels. Exp Brain Res 2006;173:267-273. 